Al-Bayyinah: Journal of Islamic Law-ISSN: 1979-7486 (p); 2580-5088 (e) Volume VI Nomor 1, pp. 17-30

\title{
PROYEKSI PENERAPAN SISTEM PEMERINTAHAN ISLAM DI NEGARA REPUBLIK INDONESIA
}

\section{H. Jamaluddin Abdullah}

(Dosen Tetap STAIN Watampone, Sulawesi Selatan, Indonesia, email: jamaludinabdullah.iainbone@gmail.com

\section{Abstract}

The projection of application sistem Islamic government in Indonesia, have a big chance even seen in social cultural Indonesia nation inspired of yuridis and politic aspects. Likewise, Islam government sistem base on syariah principle that universal can be achieved and applied by all of nation and country.

\section{Kata Kunci: Penerapan, Pemerintahan, Islam dan Indonesia.}

\section{PENDAHULUAN}

\section{A. Latar Belakang}

Indonesia dalam peta dunia Islam merupakan fenomena keislaman yang unik, berbeda dengan dunia Islam yang lainnya. Dikatakan demikian karena Indonesia berpenduduk muslim terbesar di dunia, namun sistem kenegaraan, kebangsaan, kemasyarakatan tidak didasarkan atas paham keislaman secara totalitas. Akan tetapi, justru yang dijadikan pedoman atau ideology Negara adalah pancasila yang lahir dari penggalian sejumlah nilai-nilai dasar bangsa Indonesia. Oleh Karen itu, diskursus keislaman di Indonesia senantiasa dinamis dan menarik, baik dalam skala nasional maupun internasional. ${ }^{1}$

Wacana sistem pemerintahan Islam berawal dari konsep politik Islam tentang Imamah dan Khilafah. Namun demikian, secara konseptual sistem pemerintahan Islam masih

${ }^{1}$ Marzuki Wahid \& Rumadi, Fiqh Mazhab Negara, kritik atas Politik Hukum di Indonesia (Cet. 1; Jogjakara: LKIS 2001, h. 1. 
diperdebatkan dikalangan umat Islam. Di satu pihak, sistem pemerintahan Islam telah diatur secara terperinci dan baku dalam Alquran dan Hadis, akan tetapi hanya diatur tentang prinsip-prinsip atau etika dalam melaksanakan sistem pemerintahan. Di pihak lain, sistem pemerintahan Islam dipandang sebagai keseluruhan dari ajaran Islam yang terdapat dalam Alquran dan Hadis. Dalam hal ini, sistem pemerintahan Nabi Saw di Madinah menjadi referensi sistem pemerintahan Islam sebagai landasan strategis untuk melakukan syi'ar Islam. ${ }^{2}$ Dengan demikian secara teoritik dan praktis, sistem pemerintahan Islam telah dicontohkan oleh Nabi Saw di Madinah dengan prinsip-prinsip dasarnya dituangkan dalam Piagam Madinah. ${ }^{3}$

Dalam piagam Madinah, ditemukan prinsip-prinsip pemerintahan dan sekaligus menjadi landasan dalam menjalankan sistem pemerintahan Islam, yaitu saling menghargai dan membangun sikap toleransi antara orang-orang Islam dan orang-orang yang non Islam, termasuk orang-orang Yahudi di Madinah. Di samping itu, piagam Madinah juga mengikat orang-orang Islam dan seluruh warga yang tinggal di Madinah tergabung dalam satu masyarakat yang secara fisik maupun politis berbeda dengan kelompok lain. ${ }^{4}$

Deskripsi tentang perjalanan pemerintahan Islam Madinah yang dibangun Nabi Saw, mengingatkan kepada umat Islam untuk melihat kembali realitas pemerintahan yang ada di Indonesia. Pembacaan realitas perjalanan pemerintahan Negara Indonesia, belum memperlihatkan prestasi besar dalam menegakkan keadilan sebagai indicator demokratisasi dalam sebuah Negara. Pemerintah yang seharusnya menjadi pelayan rakyat, terbalik menjadi penindasan hak-hak rakyat. Supremasi hukum yang semestinya menjadi tata aturan yang melindungi dan membela harkat dan martabat bangsa, ternyata dijadikan alat politik untuk melindungi kekuasaan. Kondisi Negara yang

2 Khalid Ibrahim Jindan, The Islamic Theory of Government According to Ibn Taymiyah, diterjemahkan oleh Masrohin dengan judul, Teori politik Islam, Telaah Kritis Ilmu Taimiyah Tentang Pemerintahan Islam (Cet. III; Surabaya: Risalah Gusti, 1999), h. 1.

${ }^{3}$ Ibid.

${ }^{4}$ Ibid. 
demikian, lebih diperparah dengan maraknya tindakan anarkisme, brutalisme dan main hakim sendiri. Kondisi ini diperparah dengan terjadinya konflik demi konflik yang terjadi beberapa tahun terakhir ini, telah menjadi potret buram sejarah kemanusiaan bagi Negara Indonesia. Misalnya kerusuhan Pekalongan (1995), Tasikmalaya (1996), Situbondo (1997), Rengasdegklok (1997), Sanggau Ledo (1995), Kalimantan Barat (1996 dan 1997), Poso (2000), sampai yang terjadi di Ambon dan Maluku sejak 1999, peristiwa Monas tahun 2008, dan lainlain.

Dalam konteks tersebut, tidak heran jika masyarakat mempertanyakan sistem pemerintahan yang selama ini dilaksanakan. Bahkan sebagian masyarakat menuding bahwa sistem pemerintahan yang diterapkan selama ini telah gagal dan tidak efektif. Dengan demikian, di kondisi yang dilematis tersebut, dirasakan pentingnya mempertimbangkan kembali konstruksi sistem pemerintahan Negara Indonesia yang mampu membawa segenap bangsa Indonesia dalam kondisi yang damai, makmur dan berkeadilan.

Dalam konteks tersebut, wacana penerapan sistem pemerintahan Islam dipandang solusi terbaik dalam memecahkan berbagai problematika berbangsa dan bernegara di Indonesia. Argumentasi yang mendasar atas wacana penerapan sistem pemerintahan Islam, dibangun dengan pendekatan historis bahwa sebelum Negara Indonesia diproklamirkan pada tanggal 17 agustus 1945, telah dirumuskan konstitusi pemerintahan yang dinamakan piaga Jakarta. Dalam piagam Jakarta ditemukan rumusan konstitusi dengan kewajiban menjalankan hukum Islam bagi pemeluk-pemeluknya ${ }^{5}$. Dengan demikian, wacana untuk membangun satu sistem pemerintahan yang lebih mengedepankan nilai-nilai Islam yang berkeadilan dan berkeadaban, dipandang sebagai sesuatu yang abash dan mensejarah di Indonesia.

${ }^{5}$ Lihat, Anwar Harjono, Indonesia Kita, pemikiran berwawasan ImanIslam (Cet. 1; Jakarta: Gema Insani Press, 1995, h. 92-93. 


\section{B. Rumusan Masalah}

Wacana penerapan sistem penerapan Islam di Indonesia, telah menorehkan sejarah tersendiri dalam perjalanan bangsa Indonesia sejak mendapatkan kemerdekaannya hal ini dimulai dengan adanya rumusan Piagam Jakarta yang dikehendaki menjadi teks deklarasi kemerdekaan Negara Indonesia dan berdirinya sistem pemerintahan Islam. Sampai sekarang wacana penerapan sistem pemerintahan Islam di Indonesia, masih tetap menjadi mainstream. Oleh karena itu masalah mendasar yang akan di bahas dalam tulisan ini adalah bagaimana proyeksi penerapan sistem pemerintahan Islam dalam wadah Negara Kesatuan Republik Indonesia.

\section{Kerangka Teori}

Sistem pemerintahan Islam oleh sebagian orang selalu diidentikkan dengan Negara Islam. Yusuf al-Qardawy mengemukakan bahwa daulah atau Negara Islam adalah daulah konstitusional, tercermin dalam prinsip-prinsip Islam dan hukum-hukum syariat yang terdapat dalam Alquran dan yang dijelaskan di dalam Sunah Nabi. Oleh karena itu, daulah bukan hanya sebuah pilihan untuk komitmen terhadap konstitusi atau hukum perundang-undangan dalam suatu sistem pemerintahan, akan tetapi merupakan tuntutan keislaman dan dalil keimanan. ${ }^{6}$

Artikulasi pemerintahan Islam dalam sistem kenegaraan, pada dasarnya mengandung makna ajaran Islam secara totalitas yang meliputi akidah, syari'ah dan akhlak. Hal ini berbeda dengan pandangan Barat yang mempersamakan al-din dengan konsep religion yang hanya mengandung konotasi agama dalam arti bahasa Indonesia. Oleh karena itu, totalitas ajaran Islam sebagai al-din mensyaratkan pemaknaan tiga komponen yang tidak terpisahkan. ${ }^{7}$ Dengan demikian, pemaknaan terhadap sistem pemerintahan Islam memiliki karakteristik yang holistik

6 Lihat, Yusuf al-Qardawy, Min Fiqhid-Daulah fil-Islam, diterjemahkan oleh Kathur Uhardi dengan judul, Fiqh Daulah (Cet.1; Jakarta: Pustaka Al-kautsar, 1997), h. 46-47.

Lihat, M. Tahir Azhary, Negara Hukum, suatu studi tentang Prinsipprinsipnya, Implementasinya pada Periode Negara Madinah dan masa kini (Cet. 1; Jakarta: Bulan Bintang, 1992), h. 21-23. 
yang berbeda dengan konsep religion yang hanya seperangkat doktrin ritual.

Dalam konteks tersebut, sistem pemerintahan Islam telah diterapkan oleh Nabi Saw di Madinah. Oleh karena itu, sistem pemerintahan Islam Nabi Saw di Madinah di pandang sebagai konsep pemerintahan Islam. Dalam hal ini terhadap sebuah konstitusi tertulis yang dilahirkan melalu konveksi ini kemudian menjadi dokumen terkenal yang dinamakan shahifah atau Piagam Madinah. Konstitusi tersebut merupakan konstitusi pertama dalam ajaran Islam, bahkan sejarah kemanusiaan. ${ }^{8}$

Piagam Madinah memang sengaja dibuat Nabi Saw, mengingat latarbelakang masyarakat Madinah ketika itu yang multi etnis dan agama, sekaligus sebagai upaya menghindari menguatnya opini faksimisme ${ }^{9}$ agama dan etnis dalam Negara. Dengan demikian, piagam Madinah merupakan suatu perjanjian yang mengikat semua elemen masyarakat, dipandang sebagai kerangka kerja pemerintahan Nabi Saw atau sistem pemerintahan Islam. Oleh karena itu, piagam Madinah juga dapat disebut sebagai langkah politik Nabi Saw yang harus dilakukan dalam kondisi masyarakat yang multikultural. Ini berarti bahwa piagam Madinah merupakan kontrak politik yang dideklarasikan oleh Nabi Saw sebagai kepala Negara kepada seluruh warga Negaranya. ${ }^{10}$

Kaitannya dengan sistem pemerintahan Islam, piagam Madinah Menjadi acuan dalam menjalankan sistem pemerintahan dalam Islam. Oleh karena itu, beberapa ketentuan yang sangat prinsipil dalam piagam Madinah, dipandang sebagai

${ }^{8}$ Lihat, Syukron Kamil, Islam dan Demokrasi; Telaah Konseptual dan Historis (Cet. 1; Jakarta: Gaya Media Pratama, 2002), h. 90.

${ }^{9}$ Faksimisme, dari asal kata faksi yang artinya kelompok, yang umumnya anggota para politisi yang mendorong perpecahan dalam partainya, bahkan dalam Negara sekalipun. Jadi faksimisme adalah suatu faham yang biasa dikembangkan para politisi dengan mendorong adanya perpecahan dalam suatu Negara. Lihat, Departemen Pendidikan dan Kebudayan, Kamus Besar Bahasa Indonesia, Ed.III; (Cet.II; Jakarta: Balai Pustaka, 2002), h. 312 .

${ }^{10}$ Lihat, A Gaffar Azis, Al-Din wa al-siyasah fil adyan al-Tsalatsa, diterjemahkan oleh Ilyas Siraj dengan judul, Berpolitik untuk Agama; Misi Islam, Kristen dan Yahudi tentang Politik (Cet. I; Yogyakarta: Pustaka Pelajar, 2002), h. 138. 
konsep sistem pemerintahan yang mendapat legitimasi syar'i. ketentuan yang dimaksud antara lain:

1. Tidak satu kelompok pun seluruh masyarakat yang turut menandatangani piagam ini membentuk satu kesatuan kebangsaan.

2. Jika diantara kelompok yang turut menandatangani piagam ini diserang oleh musuh, maka kelompok yang lain harus membelanya dengan menggalang kekuatan gabungan.

3. Diperkenankan mengadakan persekutuan dengan kafir Quraisy atau memberikan perlindungan kepada mereka atau membantu mereka mengadakan perlawanan terhadap masyarakat Madinah.

4. Orang Islam, Yahudi dan seluruh warga Madinah yang lain bebas memeluk agama dan keyakinan masing-masing dan mereka dijamin kebebasannya dalam menjalankan ibadah masing-masing. Tidak seorang pun dibenarkan mencampuri urusan agama lain.

5. Urusan pribadi atau perseorangan dan perkara-perkara kecil kelompok non muslim tidak harus melibatkan pihak-pihak lain secara keseluruhan.

6. Setiap bentuk penindasan dilarang.

7. Mulai hari ini, semua bentuk pertumpahan darah, pembunuhan, dan penganiayaan diharapkan di seluruh Negara Madinah.

8. Muhammad Saw. Adalah kepala Negara Madinah dan memagang kekuasaan peradilan tertinggi.

Pada konteks tersebut, piagam Madinah dipandang sebagai rumusan sistem pemerintahan yang melibatkan rakyat dalam sebuah pengelolaan Negara. ${ }^{12}$ Oleh karena itu, sistem pemerintahan Islam adalah sistem pemerintahan yang demokratis dengan memberikan ruang bagi rakyat dan seluruh elemen masyarakat untuk terlibat dan berpartisipasi dalam pengelolaan Negara.

${ }^{11}$ Lihat, K. Ali, Sejarah Islam dari awal sampai Runtuhnya Dinasti Usmani (Tarikh pra Modern) (Cet. IV; Jakarta: Raja Grafindo Persada, 2003), h. 66-67.

${ }^{12}$ Ibid, h. 67-68. 


\section{Metode Penelitian}

a. Pengumpulan Data

Dalam mengumpulkan data-data yang dibutuhkan, dilakukan melalui library research (baca; penelitian kepustakaan) yaitu mengulas, menyadur dan mengutip bahan dari buku-buku (literature) atau kepustakaan yang ada kaitannya dengan masalah yang dibahas, baik dalam bentuk buku, makalah dan artikel-artikel serta karya ilmiah lainnya yang dianggap representatif.

b. Analisis Data

Data yang berupa ulasan, gagasan, dan pendapat para pakar, dianalisis secara deskriptif kualitatif dengan menggunakan pendekatan sosiologis filosofis. Analisis terhadap seluruh data yang ada dilakukan secara kritis dengan menggunakan metode induktif dan deduktif. Analisis data secara induktif adalah sejumlah data yang sifatnya khusus, dikembangkan secara silogisme untuk selanjutnya ditarik suatu kesimpulan yang runtut. Sedangkan metode deduktif berangkat dari data yang sifatnya umum dan dikembangkan secara silogisme untuk selanjutnya ditarik kesimpulan.

\section{SISTEM PEMERINTAHAN ISLAM DAN PENERAPANNYA DI INDONESIA}

Dialektika wacana penerapan sistem pemerintahan Islam di Indonesia, tampak berbagai tema-tema diskursus keislaman, seperti penegakan syari'at Islam relasi agama dan Negara, Islam politik dan lain sebagainya. Secara internal, kias balik terhadap wacana penerapan sistem pemerintahan Islam di Indonesia, senantiasa mengalami pergumulan secara dialektis antara muslim nasionalis dan muslim sekuler. Muslim nasionalis menghendaki Indonesia berasaskan Islam dan mengimplikasikan berdirinya Negara Islam (Islam state of Indonesia) sebagai medium penerapan sistem pemerintahan Islam, dengan alasan bahwa mayoritas bangsa Indonesia adalah Muslim. Sedangkan muslim sekuler sebagai antitesa dari muslim nasionalis adalah kelompok yang tidak menghendaki Negara Indonesia berdasarkan Islam dan didirikannya Negara Islam Indonesia, dengan alasan bahwa bangsa Indonesia tidak hanya dibangun 
oleh orang Islam, akan tetapi non muslim juga turut andil mendirikan Negara Indonesia.

Kaitannya dengan hal tersebut, menurut Nurcholis Madjid bahwa mendirikan Negara Islam adalah historis atau tidak dikenal dalam kesejahteraannya. Dikatakan demikian karena menurut Cak Nur (Nurcholis Madjid) bahwa baru tiga hari Nabi Saw dimakamkan, umat rebut karena suksesi karena pola suksesi yang tidak jelas, maka yang terjadi adalah ketidakjelasan pula. Oleh karena itu, masalah kenegaraan tidak menjadi bagian integral dari Islam. Munculnya gagasan Negara Islam atau Islam sebagai Negara tidak lain merupakan bentuk kecenderungan apologik yang muncul dari dua kecenderungan; pertama, karena apologik ideologi Barat seperti demokrasi, sosialisme, komunisme, dan lainnya. Kedua, karena legalisme yaitu sebuah apresiasi Islam yang serba legal formal, padahal Islam tidak dipandang semata-mata sebagai struktur dan kumpulan hukum. ${ }^{14}$

Lebih jauh Cak Nur berpendapat bahwa konsep Negara Islam merupakan distorsi hubungan proporsional antara agama dan Negara. Negara adalah segi kehidupan duniawi yang dimensinya adalah rasional dan kolektif, sedangkan agama adalah aspek kehidupan yang dimensinya spiritual sifatnya pribadi (privat).${ }^{15}$ Memang diakui bahwa hubungan agama dan politik yang sangat erat, akan tetapi berbeda di antara keduanya dari segi teknis dan praktisnya. Agama (Islam) merupakan berita suci yang diterima Rasul dari Tuhan, sedangkan politik adalh wewenang kemanusiaan khususnya menyangkut teknis structural dan prosedural. Oleh karena itu, politik (sistem kenegaraan) dibedakan dari agama dari segi susunan formal struktural dan praktis duniawi. ${ }^{16}$ Dengan demikian, umat Islam tidk perlu menuntut formalisasi agama (Negara Islam) karena sebagai sistem nilai hanya ditujukan kepada pribadi setip

13 Lihat, Cliford Gertz dalam Norcholis Madjid, Islam Agama Kemanusiaan, Membangun Tradisi dan Visi baru Islam Indonesia (Cet. I; Jakarta: Paramadina, 1995), h. 3-4.

${ }^{14}$ Ibid, h. 40-41.

${ }^{15}$ Muhammad Tahir Azhari, Op. Cit., h. 33.

${ }^{16}$ Sayyid Husain Nasr, et al., Jurnal Pemikiran Paradimana (Jakarta: Paramadina, 1998), h. 49. 
pengikutnya, olehnya itu yang penting adalah subtansinya dan bukan bentuk formalnya. ${ }^{17}$

Pada konteks tersebut, Rasyidi justru berpendapat bahwa pandangan yang mengatakan Negara Islam merupakan distorsi hubungan proporsional antara Islam dan Negara, tidak relevan dengan apa disinyalir dalam Alquran. ${ }^{18}$ Dikatakan demikian karena dalam Alquran terdapat prinsip-prinsip kenegaraan seperti musyawarah, rule of law, persamaan hak pluralitas penduduk, prinsip kemerdekaan beragama, kerjasama internasional, pemerataan kekayaan antara warga Negara, hukuman berat kepada pelanggar kesusilaan baik pencurian harta (orang atau negara) atau gangguan terhadap kehormatan (seks). Oleh karena itu, jika penerapan sistem pemerintah Islam dalam wadah Negara Islam sebagai distorsi hubungan proporsional antara negara dan agama, justru itulah yang mengalami distorsi karena tidak berdasar pada Alquran. Bahkan dapat dikatakan bahwa pemisahan antara Negara dan agama (Islam) adalh warisan dari Paus di Roma pada abad pertengahan. ${ }^{19}$

Kaitannya dengan sistem pemerintahan Islam, Gus Dur berpendapat bahwa Islam sama sekali tidak memiliki bentuk Negara, akan tetapi yang terpenting dalam sistem pemerintahan Islam adalah etika kemasyarakatan. Dikatakan demikian karena Islam pada dasarnya tidak memiliki konsep pemerintahan definitif, Islam hanya bias dimanifestasikan dalam proses pengembangan etika sosial yang memungkinkan tercapainya kesejahteraan kehidupan sosial. Dengan demikian, penerapan sistem pemerintahan Islam dalam wadah Negara Islam di Indonesia secara formal, tidak perlu diperjuangkan. Akan tetapi, yang harus diperjuangkan adalah mengintegrasikan keislaman dan keindonesiaan dengan konsep yang konkrit dalam sistem pemerintahan Negara Indonesia yang berdasarkan Pancasila dan UUD $1945 .^{20}$

17 Lihat, Ahmad Amir Aziz, Neo Modernism Islam di Indonesia; Gagasan Sentral Nurcholish Madjid dan Abdurrahman Wahid (Cet. I; Jakarta: Rineka Cipta, 1999), h. 41.

\footnotetext{
${ }^{18}$ Ibid.

${ }^{19}$ Muhammad Thahir Azhari, op. cit., h. 33-34.

${ }^{20}$ Lihat Ahmad Amir Aziz, op. cit., h. 42-45.
} 
Dalam konteks proyeksi penerapan sistem pemerintahan Islam di Indonesia, pada dasarnya merupakan wacana yang niscaya, dengan beberapa paradigm, antara lain: pertama, realitas Indonesia sebagai Negara yang mempunyai penduduk Islam terbesar di dunia. Keniscayaan penerapan sistem pemerintahan Islam di Indonesia, akan terwujud apabila terbangun proses penyadaran umat Islam Indonesia tentang universalitas Islam dengan tidak mengabaikan asas-asas demokrasi di tengah-tengah pluralitas kebangsaan.

Kedua, proyeksi penerapan sistem pemerintahan Islam di Indonesia, dilihat dari aspek kesejarahannya. Kemerdekaan bangsa Indonesia merupakan andil dari umat Islam Indonesia yang dibekali oleh semangat jihad Islam (bela Negara). Sejarah bias membuktikan bagaimana perjuangan menegakkan Negara Islam masa penjajahan Belanda sebelum kemerdekaan yang dikenal dengan perang Padri (1802-1862), perang Jawa dan perang Banjar yang masing-masing dipimpin oleh Muhammad bin Abdul Wahab, Haji Miskin, Haji Abdurrahman dan Haji Muhammad Arif di Sumatra Barat. Pangeran Diponegoro (1830), Pangeran Antasari dan Pangeran Hidayat (1859-1862). ${ }^{21}$

Ketiga, dari sudut pandang konstitusi, penerapan sistem pemerintah Islam mempunyai legitimasi yang kuat. Dikatakan demikian karena pancasila dan UUD 1945 memberikan ruang yang seluas-luasnya bagi umat Islam untuk menjalankan ajaran Islam. Oleh karena itu, sistem pemerintahan sebagai bagian yang tidak terpisahkan dari totalitas ajaran Islam, dipandang sebagai suatu yang legitimated dalam konstitusi Negara Indonesia.

Keempat, pergulatan politik Nasional belakangan ini, ditujukan dengan realitas sejumlah partai politik dan ormasormas Islam yang intens menyuarakan penerapan sistem pemerintahan Islam. Realitas itu merupakan momentum untuk menawarkan konsep pemerintahan Islam yang terkonstruksi dari prinsip-prinsip amanah, keadilan dan musyawarah.

Dengan demikian, proyeksi penerapan sistem pemerintahan Islam di Indonesia, mempunyai indikator kuat dengan adanya respon umat Islam Indonesia terhadap cita-cita

21 Abd. Kadir Djaelani, Sekitaran Pemikiran Politik Islam (Cet. I: Jakarata: Media Dakwah. 1994), h. 265-271. 
pemerintahan Islam. Berbagai kelompok pergerakan Islam yang muncul baik dalam sektor politik maupun pada tingkat diskursif adalah momentum besar untuk menyatukan kekuatan membangun konsolidasi dan menyatukan visi politik Islam secara teori maupun praktis sehingga mampu mewujudkan citacita pemerintahan Islam sebagai tujuan bersama.

Keniscayaan penerapan sistem pemerintahan Islam di Indonesia semakin menemukan vitalitasnya. Dikatakan demikian karena konstruksi sistem pemerintahan yang diterapkan selama ini, tampaknya telah gagal membangun tatanan kenegaraan yang harmonis dan humanis. Hal itu dapat dilihat dengan meningkatnya kejahatan sosial, politik dan ekonomi, sehingga rakyat bertambah miskin, kecemburuan sosial makin tinggi, pada gilirannya melahirkan konflik sosial yang menjadi catatan buram bagi sejarah kemanusiaan. Pada tataran itulah pemerintahan Islam menjadi alternatif yang solutif dari berbagai masalah ketatanegaraan yang telah gagal.

Penerapan sistem pemerintahan Islam di Indonesia, memiliki heterogenitas sosial yang dapat diterima oleh segenap bangsa Indonesia yang plural. Dikatakan demikian karena sistem pemerintahan Islam sebagai mana yang telah di contohkan oleh Nabi Saw di Madinah, mempunyai prinsip yang universal, seperti amanah, keadilan, dan musyawarah serta akomodatif terhadap perbedaan. Namun, perlu digaris bawahi bahwa term-term pemerintahan seperti; khilafah, imamah dan sebagainya, tidak perlu dipersoalkan, karena yang terpenting dalam sistem pemerintahan Islam adalah perwujudan nilai-nilai universal sebagai landasan hidup (way of life) atau ideologi Negara.

Di samping itu, penerapan sistem pemerintahan Islam di Indonesia, juga tidak signifikan apabila dikaitkan dengan Negara Islam. Dalam artian bahwa Negara Islam tidak menjadi syarat mutlak bagi penerapan sistem pemerintahan Islam. Oleh karena itu, Indonesia tidak perlu dijadikan sebagai Negara Islam karena sistem pemerintahan Islam bersifat universal dan dapat mempola dalam semua bentuk Negara. Konstitusi Negara Republik Indonesia, telah memberikan legitimasi yuridis bagi penerapan sistem pemerintahan Islam untuk terintegrasi dan diterapkan dalam sistem kenegaraan Indonesia. 


\section{PENUTUP}

\section{A. Simpulan}

Mengacu pada uraian yang telah dikemukakan diatas, maka ditarik simpulan bahwa proyeksi penerapan sistem pemerintahan Islam di Indonesia, mempunyai peluang dan ruang yang luas dan mempunyai legitimasi yurudis yang konstitusional. Di samping itu, penerapan sistem pemerintahan Islam di Indonesia, juga mempunyai landasan historis, sosiologis dan politik. Sedangkan dari segi konseptual, sistem pemerintahan Islam dibangun di atas prinsip-prinsip syariat yang universal, sehingga dapat mempola dan diterapkan pada semua bentuk Negara, termasuk Negara Indonesia.

\section{B. Saran}

Dalam konteks penerapan sistem pemerintahan Islam di Indonesia, diperlukan suatu kesadaran dari umat Islam dan kemampuan umat Islam untuk memberikan keyakinan kepada segenap elemen bangsa Indonesia bahwa sistem pemerintahan Islam adalah milik semua warga Negara dan untuk kepentingan Negara dalam mewujudkan cita-cita luhurnya sebagaimana yang tertuang dalam UUD 1945 sebagai konstitusi Negara. Oleh karena itu, penerapan sistem pemerintahan Islam di Indonesia tidak perlu dikaitkan dengan term khalifah imamah dan Negara Islam, karena hal itu dipandang tidak substansial dan strategis. 


\section{DAFTAR PUSTAKA}

Ali, K. Sejarah Islam dari awal sampai Runtuhnya Dinasti Usmani (Tarikh pra Modern) Cet. IV; Jakarta: Raja Grafindo Persada, 2003.

Azhary, Muh. Tahir Negara Hukum, suatu studi tentang Prinsip-prinsinya, Implementasinya pada Periode Negara Madinah dan masa kini Cet. 1; Jakarta: Bulan Bintang, 1992.

Azis, A Gaffar Al-Din wa al-siyasah fil adyan al-Tsalatsa, diterjemahkan oleh Ilyas Siraj dengan judul, Berpolitik untuk Agama; Misi Islam, Kristen dan Yahudi tentang Politik Cet. I; Yogyakarta: Pustaka Pelajar, 2002.

Aziz, Ahmad Amir, Neo Modernism Islam di Indonesia; Gagasan Sentral Nurcholish Madjid dan Abdurrahman Wahid Cet. I; Jakarta: Rineka Cipta, 1999

Departemen Pendidikan dan Kebudayaan, Kamus Besar Bahasa Indonesia, Ed. III, Cet. II; Jakarta: Balai Pustaka, 2002.

Djaelani, Abd. Kadir, Sekitaran Pemikiran Politik Islam Cet. I: Jakarta: Media Dakwah. 1994.

Harjono, Anwar Indonesia Kita, pemikiran berwawasan ImanIslam (Cet. 1; Jakarta: Gema Insani Press, 1995.

Jindan, Khalid Ibrahim The Islamic Theory of Government According to Ibn Taymiyah, diterjemahkan oleh Masrohin dengan judul, Teori politik Islam, Telaah Kritis Ilmu Taimiyah Tentang Pemerintahan Islam Cet. III; Surabaya: Risalah Gusti, 1999.

Kamil, Syukron Islam dan Demokrasi; Telaah Konseptual dan Historis Cet. 1; Jakarta: Gaya Media Pratama, 2002. 
Madjid, Norcholis, Islam Agama Kemanusiaan, Membangun Tradisi dan Visi baru Islam Indonesia Cet. I; Jakarta: Paramadina, 1995.

Nasr, Sayyid Husain, et al., Jurnal Pemikiran Paramadina Jakarta: Paramadina, 1998.

Qardawy, Yusuf Min Fiqhid -Daulah fil-Islam, diterjemahkan oleh Kathur Uhardi dengan judul, Fiqh Daulah Cet.1; Jakarta: Pustaka Al-kautsar, 1997.

Wahid, Marzuki \& Rumadi, Fiqh Mazhab Negara, kritik atas Politik Hukum di Indonesia Cet. 1; Jogjakarta: L. KIS 2001. 